\title{
PENGALIHAN UTANG DALAM EKONOMI ISLAM \\ Fasiha
}

\author{
Fakultas Ekonomi dan Bisnis Islam Institut Agama Islam Negeri (IAIN) Palopo \\ Email : Fasiha@iainpalopo.ac.id
}

\begin{abstract}
Debt in the Law of Islamic economics is called Al-Hiwalah. The legal basis Hiwalah application is the Qur'an, Hadith, Ijma and qiyas. Terms and harmonious Hiwalah is Muhil (Menghilawahkan), Second; Muhtal (in hilawahkan), third; Muhal 'alaih (people receiving Hiwalah, to four; Shighat Hiwalah, namely the consent of muhil. Hiwalah concept can be applied in the form of Islamic banking Factoring or factoring, post-dated check and Bill discounting
\end{abstract}

Keywords: Debt and Hiwalah

\begin{abstract}
Abstrak
Hutang dalam Hukum ekonomi Islam disebut Al-Hiwalah. Dasar hukum penerapan Hiwalah adalah Alquran, Hadits, Ijma, dan qiyas. Syarat dan keharmonisan Hiwalah adalah Muhil, Kedua; Muhtal (dalam hilawahkan), ketiga; Muhal 'alaih (orang yang menerima Hiwalah, ke empat; Shighat Hiwalah, yaitu persetujuan muhil. Konsep konsep tersebut dapat diterapkan dalam bentuk Anjak piutang atau bank Islam, cek pasca-tanggal dan diskon tagihan)
\end{abstract}

Kata Kunci : Utang dan Hiwalah

\section{PENDAHULUAN}

Islam merupakan agama yang mengatur berbagai aspek kehidupan manusia, aspek-aspek ajaran Islam tersebut tidak dapat dipisahkan antara satu dengan yang lainnya, karena merupakan suatu hubungan yang terjalin erat sekali. Karena eratnya jalinan tersebut, maka bagian yang satu merupakan bagian dari yang lainnya, sehingga tanpa adanya salah satu bagian tersebut bagian yang lainnya tidak sempurna. Meskipun demikian, aspek-aspek ajaran Islam tersebut masih dapat dibedakan antara satu dengan yang lainnya. Setiap aspek kehidupan yang dihadapi manusia ada hukumnya (wajib, sunnah, haram, mubah), di samping juga ada hikmahnya. Sejalan dengan pertumbuhan hukum Islam, menunjukkan bahwa pengaruh adat sosial kultural 
masyarakat terhadap pembentukan hukum Islam sangatlah kuat, hal ini terlihat pada hasil ijtihad para imam madzhab. Pengaruh adat dalam kehidupan hukum adalah sesuatu hal yang tidak perlu dirisaukan. Sebab, hukum yang bersumber dari adat pada prinsipnya mengandung proses dinamis penolakan bagi yang buruk dan penerimaan bagi yang baik sesuai dengan kebutuhan objektif masyarakat. Per-soalan menjadi serius manakala partum-buhan suatu kebiasaan masyarakat, secara absolut bertentangan dengan hukum. Hukum Islam mengakomodasi adat suatu masya-rakat sebagai sumber hukum selama tradisi tersebut tidak bertentangan dengan nash al-Qur'an maupun alsunnah. ${ }^{1}$

Islam adalah pandangan hidup yang seimbang dan terpadu, di desain untuk mengantarkan kebahagiaan manusia (falah) lewat penegakan keharmonisan antara kebutuhan-kebutuhan moral dan materil manusia, dan aktualisasi keadilan sosioekonomi dan persaudaraan dalam masya-rakat. Seruan untuk kesejahteraan yang berorentasi kepada keadilan dan keseim-bangan ini di ulang-ulang setiap hari lima kali. Kaum muslimin telah memulai menyambut panggilan ini dan terdapat kebangkitan kembali di dalam dunia Islam. Kebangkitan ini tercermin dalam lapangan intelektual. Reformasi ekonomi dan reorgani sasi merupakan isi terpenting dari kebang kitan Islam, sistem ekonomi Islam juga memiliki kesempatan, perhatian yang terus bertambah. Penghapusan bunga sebagai keniscayaan ciri Islam, rekayasa sistem perbankan dan moneter bebas bunga telah menawarkan tantangan terbesar bagi ekonom muslim.

Kebangkitan ekonomi yang berbasis ajaran Islam dengan di awalinya pengkajian literatur tentang ekonomi baik dalam Al-Qur'an, Hadis dan dalam sejarah Islam sehingga menghasilkan beberapa pemikiran tentang ekonomi Islam. beberapa produk pemikiran tentang ekonomi Islam kemudian di wejantahkan dalam dunia perbankan di sebut salah satunya adalah Konsep Peng-alihan Utang yang disebut sebagai $\mathrm{Al}$ Hiwalah.

1 Said Agil Husein al-Munawar, Hukum Islam dan Pluralitas sosial, (Jakarta: Penamadani, 2004), h. 41 . 
Bank syariah mempunyai peranan sangat penting dalam pembangunan nasional karena fungsi bank adalah lembaga keu-angan yang usaha pokoknya menghimpun dana dari masyarakat dan memberikan pembiayaan, serta jasa-jasa lainnya yang pengoperasiannya disesuaikan dengan prin-sip syariah. Dalam memberikan pembiayaan, salah satu bentuk yang diberikan oleh bank syariah berupa pembiayaan murabahah. Adapula bentuk lain yang diberikan oleh bank syariah berupa al-wakalah. Pemberian pembiayaan muraba-hah bagi nasabah sangat bermanfaat untuk meningkatkan kesejahteraan hidupnya saat kekurangan dana dan membutuhkan barang. Nasabah dapat meminta bank untuk meme-nuhi kebutuhan dengan pembayaran yang dilakukan secara cicilan dalam kurun waktu yang telah disepakati. Sedangkan, al-waka-lah berarti mewakilkan kepada seseorang untuk melakukan sesuatu semisal pemba-yaran, dll. Bank syariah juga dapat membantu nasabah yang ingin melakukan take over. Take over merupakan pengalihan hutang nasabah terhadap transaksi non-syariah yang tela berjalan yang dilakukan atas permintaan nasabah. Namun, dalam penerapannya tidak menutup kemungkinan timbulnya masalah-masalah.

\section{HIWALAH}

Menurut bahasa yang di maksud dengan hiwalah ialah al-intiqai dan al-tahwil, artinya ialah memindahkan atau mengoperkan, maka Abdurrahman al-Jazili; berpendapat bahwa yang di maksud dengan hiwalah menurut bahasa adalah ${ }^{2}$

ا لنقل من محل الى محل

\section{Artinya; "Pemindahan dari satu tempat ketempat lain"}

Sedangkan pengertian hiwalah menurut istilah, para ulama berbeda pendapat dalam mendifinisikan, akan tetapi pada dasarnya sama saja. antara lain sebagai berikut:

1. Menurut Hanafiyah, yang di maksud dengan hiwalah ialah

${ }^{2}$ Hendi Suhendi, Fiqhi Muamalah (Jakarta; PT. Raja Grafindo Persada, 2002), h. 99 
نقل المطا لبة من زمة المد يون الى زمة الملتزم

Artinya; "Memindahkan tagihan dan tanggung jawab yang berutang kepada yang lain yang punya tanggung jawab kewajiban pula”.

2. Ibrahim Baqir berpendapat

$$
\text { نقل الحق من زمة المحيل الى زمة المحال عليه }
$$

Artinya; "Pemindahan kewajiban dari beban yang memindahkan menjadi beban yang menerima pemindahan"

3. Menurut Sayyid Sabiq adalah "Pemindahan dari tanggungan muhil menjadi tanggungan muhal 'alaih"

Jadi Al-hawalah adalah pengalihan utang dari orang yang berhutang kepada orang lain yang wajib menanggungnya. Secara sederhana, hal ini dapat di jelaskan bahwa A (muhal) memberikan pinjaman kepada B (muhil), sedangkan B masih mempunyai piutang kepada C (muhal 'alaih). Begitu B tidak mampu membayar utangnya pada A. ia lalu mengalihkan beban utang tersebut pada C. dengan demikian, $\mathrm{C}$ yang harus membayar utang B kepada $\mathrm{A}$, sedangkan utang $\mathrm{C}$ sebelumnya pada $\mathrm{B}$ di anggap selesai. ${ }^{3}$ Dasar penerapan dari Al Hiwalah sebagai mana berikut: ${ }^{4}$

1. Al-Qur'an

a. QS. Al-Baqarah/2:283

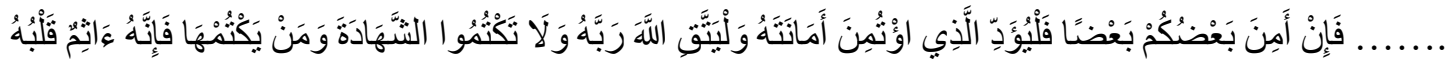

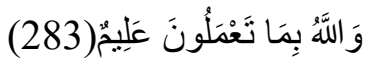

\footnotetext{
${ }^{3}$ Muhammad Syafi'I Antonio, Bank Syariah Dari Teori Ke Praktek (Jakarta; Gema Insani Press, 2001), h.. 126

${ }^{4}$ Dewan Syariah Nasional - Majelis Ulama Indonesia, Fatwa Dewan Syariah Nasional No. 31 / DSN - MUI / VI/ 2002 Tentang Pengalihan Hutang
} 
Terjemahnya:

...Akan tetapi jika sebagian kamu mempercayai sebagian yang lain, maka hendaklah yang dipercayai itu menunaikan amanatnya (hutangnya) dan hendaklah ia bertakwa kepada Allah Tuhannya; dan janganlah kamu (para saksi) menyembunyikan per-saksian. Dan barangsiapa yang me-nyembunyikan, maka sesungguhnya ia adalah orang yang berdosa hatinya; dan Allah Maha Mengetahui apa yang kamu kerjakan.

b. QS. Al-Maidah; 1-2

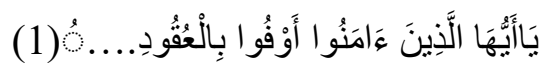

Terjemahnya;

"Hai orang-orang yang beriman, penuhilah aqad-aqad itu......"

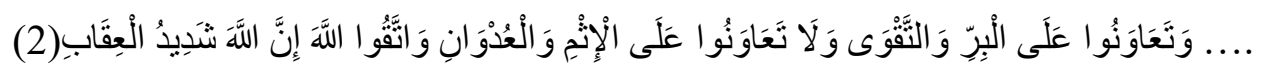

Terjemahnya;

“........ Dan tolong-menolonglah kamu dalam (mengerjakan) kebajikan dan takwa, dan jangan tolong-menolong dalam berbuat dosa dan pelanggaran. Dan bertakwalah kamu kepada Allah, sesungguhnya Allah amat berat siksa-Nya”.

c. QS. An-Nisa; 58

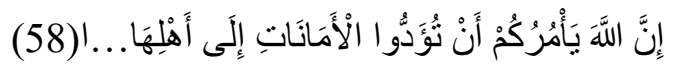

Terjemahnya:

Sesungguhnya Allah menyuruh kamu menyampaikan amanat kepada yang berhak menerimanya, ......."

2. Hadits

$$
1 \text { اد الا ما نة الى من ا نتمنكك ولا تخن من خا نك (ر و اه ابو داود و الترمزي و قال حد يث حسن) }
$$


Artinya

"Tunaikanlah amanat itu kepada orang yang memberikan amanat ke-padamu dan jangan kamu meng-hianati orang yang menghianatimu"

Hawalah dibolehkan dengan sabda Rasulullah saw.

$$
\text { مطل الغنى ظلم فاز ا اتبع احد كم على ملي فليتبع }
$$

Artinya:

Penahanan (tidak membayar hutang) bagi orang yang mampu adalah suatu kedhaliman. Dan apabila piutang seseorang dari pada kalian di serahkan kepada orang yang mampu, hendaklah ia menerima serahan itu. (Muttafaqah alaih) ${ }^{5}$

Dalam hadis tersebut di perintahkan oleh Rasulullah saw. apabila seseorang yang berhutang mengatur supaya hutangnya itu di bayar oleh orang lain yang mampu, maka pihak yang memberikan piutang hendaklah menerima pemindahan piutang itu. Berdasarkan kepada dhahir Hadis tersebut, maka kebanyakan fuqaha Hanabilah, Ibnu Jarir, Abu Tsaur dan Dhahiriyah menyata-kan wajib hukumnya pihak yang berpiutang menerima pemindahan piutang. Tetapi jumhur fuqaha, mengartikan perintah Nabi tersebut sebagai Istihbab.

\section{Ijma}

Para ulama telah berkonsensus akan keabsahan Hiwalah karena ia merupakan proses pemindahan hutang dan bukan barang.

\section{Qiyas}

Menurut methologi usul fiqhi Hiwalah dapat di analogikan dengan Al-Kafalah ${ }^{6}$

Adapun Rukun dan Syarat-syarat Hawalah

\section{Rukun Hiwalah}

5 Hamzah Ya'qub, Kode Etik Dagang Menurut Islam, "Pola Pembinaan Hidup Dalam Berekonomi” Cet. III (Bandung, CV. Diponegoro Bandung, 1999), h. 235 dan Lihat,- Muhammad Syafi'I Antonio, h. 126

6 Karnaen Perwataatmadja \& Muhammad Syafe'I Antonio, Apa dan Bagaimana Bank Islam (Yogyakarta; Dana Bhakti Wakaf, 1992), h. 38 
Menurut Hanafiyah bahwa rukun hiwalah hanya satu yakni Ijab dan kabul antara yang menghilawakan dengan yang menerima hiwalah. ${ }^{7}$ Sedangkan menurut Syafi'iyah bahwa rukun hiwalah itu ada empat yaitu: Pertama; Muhil (Meng-hiwalahkan), Kedua; Muhtal (di hiwalah-kan), ketiga; Muhal 'alaih (orang yang menerima hiwalah, Ke empat; Shighat hiwalah, yaitu ijab dari muhil. ${ }^{8}$

\section{Syarat-syarat Hiwalah}

Syarat-syarat hiwalah yakni a) yang memindahkan utang, b) Yang menerima Hiwalah adalah orang yang berakal c) Yang dihiwalahkan juga harus orang berakal. ${ }^{9}$ d) Kridhaan ketiga pihak yang bersangkutan dalam hawalah. Yakni hawalah itu baru terlaksana apabila ketiganya sepakat mene-rima dan melaksanakannya. Ada yang memandang bahwa pihak yang berpiutang (kreditur) keridlaannya bukan merupakan syarat sahnya hawalah, berlandaskan kepada hadits bahwa ia diperintahkan (wajib mene-rima pemindahan piutangnya, e) Hutang yang di pindahkan itu mesti jelas ( $m a$ 'lum) jumlahnya dan sifatnya, f) Hutang yang di pindahkan itu sama dengan hutang yang baru mengenai besar dan sifatnya (Kualitas-nya) ${ }^{10}$

Macam-Macam Hiwalah

Menurut mazhab Hanafi, hiwalah dikelompokkan menjadi dua, yaitu muth-laqah (umum) dan muqayyadah (terikat). ${ }^{11}$

1. Hiwalah muthlaqah yaitu hiwalah terjadi ketika seseorang memindahkan hutang-nya agar ditanggung muhal 'alaih, se-dangkan ia tidak mengaitkan dengan hutang piutang mereka, sementara muhal 'alaih menerima hiwalah. Ulama selain mazhab Hanafi tidak membolehkan hiwalah semacam ini. Sebagian ulama berpendapat, pengalihan utang secara mutlak ini termasuk

\footnotetext{
${ }^{7}$ Lihat,- Hendi Suhendi, op cit, h. 101

${ }^{8}$ Ibid,- h. 102

${ }^{9}$ bid,- h. 101

10 Hamzah Ya'qub, Kode Etik Dagang Menurut Islam, "Pola Pembinaan Hidup Dalam Berekonomi” Cet. III (Bandung, CV. Diponegoro Bandung, 1999), h. 236

${ }^{11}$ Syafi'i Antonio, Bank Syariah Wacana Ulama dan Cendikiawan, (Jakarta: Tazkia Institut, 1999),
} h. 205 
kafalah mahdhah (jaminan). Untuk itu harus didasarkan pada kerelaan tiga pihak yaitu orang yang punya piutang, orang yang berhutang dan orang yang menanggung hutang

2. Hiwalah muqayyadah adalah jika orang yang berhutang memindahkan beban hutangnya tersebut pada muhal 'alaih dengan mengaitkan pada hutang muhal 'alaih padanya. Inilah hiwalah yang dibolehkan berdasarkan kesepakatan ulama.

Ada sedikit perbedaan hukum antara hiwalah mutlaqah dengan hiwalah muqayyadah. Perbedaan itu adalah sebagai berikut:

1. Apabila hiwalah itu bersifat mutlaqah, sedangkan muhal 'alaih tidak berutang kepada muhil, maka muhal menagih hutang hiwalah kepada muhal 'alaih, atau muhal 'alaih berhutang kepada muhil tanpa mengaitkan dengan hutang tersebut. Muhal 'alaih pun tidak kebe-ratan dengan beban tambahan tersebut, maka muhal 'alaih akan ditagih untuk membayar dua macam hutang sekaligus, yaitu hutang hiwalah dan hutang pada muhil, muhal menuntut bayar hutang hiwalah dan muhil membayar hutang terhadapnya. Apabila muhil membatasi hiwalah pada hutangnya kepada muhal, maka muhil tidak boleh menuntut muhal 'alaih untuk melunasi hutang kepadanya, maka terjadi muqashah antara muhal 'alaih dan muhil.

2. Apabila hiwalah itu bersifat muqay-yadah, sedangkan muhal 'alaih sudah bebas dari hutang pada muhil maka batallah hiwalah. Tapi apabila hiwalah itu bersifat mutlaqah dan muhal 'alaih sudah lepas dari hutang, maka hiwalah tidak batal.

3. Muhil mungkin meninggal sebelum muhal 'alaih melunasi hutang kepada muhal. Muhil juga mempunyai hutang pada orang-orang selain muhal. Sedang-kan muhil tidak mempunyai harta apapun selain piutang yang ada pada muhal 'alaih. Jika hiwalah mereka bersifat muqayyadah. Muhal boleh mengambil piutang tersebut meskipun harus dibagi dengan para pemilik piutang lainnya. Jika hiwalah itu bersifat mutlaqah, maka semua piutang 
muhil yang ada pada muhal 'alaih dapat diambil untuk dibagi-bagi kepada orang-orang yang punya piutang kepada muhil, kecuali pada muhal yang memang tidak berhak atas pembagian tersebut. Hak muhal tetaplah piutangnya yang telah dihiwalahkan kepada muhal 'alaih. Dengan kata lain muhal 'alaih tetap harus menunaikan kewajibannya kepada muhal.

Hiwalah dari segi objek akad dibagi menjadi dua, yaitu hiwalah al-haq dan hiwalah al-dain sebagai berikut: ${ }^{12}$

1. Hiwalah al-haq adalah pemindahan hak (piutang) dari seseorang pemilik kepada pemilik piutang lainnya. Biasanya itu dilakukan bila pihak pertama mem-punyai hutang kepada pihak kedua. Ia membayar hutang itu bukan dalam bentuk barang/benda, maka perbuatan tersebut dinamakan sebagai hiwalah haq. Pemilik piutang dalam hal ini adalah muhil karena dia yang memin-dahkan kepada orang lain untuk mengembalikan haknya.

2. Hiwalah ad-dain adalah lawan dari hiwalah al haq yaitu pengalihan hutang dari seseorang penghutang kepada penghutang lainnya. Ini dapat dilakukan karena penghutang pertama masih mempunyai piutang, karena ia memindahkan kepada orang lain untuk mem-bayar hutangnya

Aplikasi Al Hawalah dalam Perbankan

Take over berarti mengambil alih, atau dalam lingkup suatu perusahaan adalah perubahan kepentingan pengendalian suatu perseroan. Terkait itu, take over syariah adalah pembiayaan yang timbul sebagai akibat dari take over terhadap transaksi non-syariah yang telah berjalan yang dilakukan oleh bank syariah atas permintaan nasabah. Berdasarkan Fatwa Dewan Syari-ah Nasional, take over disebut juga peng-alihan hutang. Pengalihan hutang yang dimaksud disini adalah pengalihan transaksi non-syariah yang telah berjalan menjadi transaksi yang sesuai dengan syariah. Take over merupakan proses perpindahan kredit nasabah di bank

12 Sutan Remy Sjahdeini, Perbankan Islam dan Kedudukannya dalam tata Hukum Perbankan Indonesia, cet. 1 (Jakarta: Pustaka Utama Grafiti, 1999), h. 95 
konvensional menjadi pembiayaan dengan prinsip jual beli yang berdasarkan syariah. Pada proses take over ini, bank syariah sebagai pihak yang akan melakukan take over terhadap kredit yang dimiliki calon nasabahnya di bank konven-sional. Bertindak sebagai wakil dari calon nasabahnya untuk melunasi sisa kredit yang terdapat di bank asal, mengambil bukti lunas, surat asli agunan, perizinan, polis asuransi, sehingga barang (yang dikredit-kan) menjadi milik nasabah secara utuh. Kemudian, untuk melunasi hutang nasabah kepada bank syariah, maka nasabah tersebut menjual kembali (barang yang dikreditkan) tersebut kepada bank syariah. Kemudian, bank syariah akan menjual lagi kepada nasabah dengan pilihan kombinasi akad yang tertera dalam Fatwa Dewan Syari'ah Nasional No: 31/DSN-MUI/VI/2002 ten-tang Pengalihan Hutang.

Penerapan kontrak hawalah dalam sistem perbankan biasanya di tetapkan pada hal-hal berikut:

1. Faktoring atau anjak piutang, di mana para nasabah yang memiliki piutang kepada pihak ketiga memindahkan piutang itu kepada bank, bank lalu membayar piutang dan menagihnya dari pihak ketiga itu.

2. Post-dated check, di mana bank bertindak sebagai juru tagih, tanpa membayar dulu piutang tersebut

3. Bill discounting, secara prinsip, bill discounting serupa dengan hawalah, hanya saja, dalam Bill discounting, nasabah harus membayar fee, sedangkan pembahasan fee tidak di dapati dalam kontrak hawalah. ${ }^{13}$

Perbankan syariah tidak menganut sistem bunga, namun lebih mengedepankan rasa tolong menolong, salah satunya yaitu dalam fasilitas take over yang ada di bank Syariah. Take over yang ada di sini yaitu pengalihan utang dari bank ke bank, yang mana nasabah mempunyai utang ke bank A kemudian mengalihkannya ke bank B, yaitu dengan cara bank B memberikan qardh kepada nasabah dan dengan qardh tersebut nasabah dapat melunasi utang yang ada di bank lama, qardh berupa pinjaman

${ }^{13}$ Lihat,- Muhammad Syafi'I Antonio, Bank Syariah.....op cit, h. 12 
tanpa adanya tambahan karena setiap tambahan mengan-dung riba. Setelah nasabah melunasi utang yang ada di bank lama nasabah pun terbebas dan tidak mempunyai tanggungan, akan tetapi nasabah mempunyai tanggungan untuk melunasi qardh yang telah diberikan oleh bank B. Berikut ini Sifat-sifat dari fasilitas pengalihan Al-Hiwalah:

1. Kebanyakan ulama tidak memperboleh-kan pengambilan manfaat (imbalan) atas pengalihan hutang-piutang tersebut antara lain dengan menguragi jumlah piutang atau menambah jumlah hutang tersebut

2. Bank hanya boleh membebankan fee atas jasa penagihan ${ }^{14}$

3. Dalam dunia perbankan Hiwalah dapat diterapkan dalam proses "Debt Transfer"

4. Mengacu pada pengertian di atas debt transfer dapat di lakukan karena: seandai-nya $\mathrm{A}$ berhutang ke $\mathrm{C}$ dan $\mathrm{B}$ berhutang ke $\mathrm{A}$ atas permintaan $\mathrm{A}$ dapat melakukan pembayaran ke C. dalam hal ini; A. Dapat dianggap sebagai nasabah, B; Dapat dianggap sebagai bank, C; dapat dianggap sebagai mitra usaha nasabah

Hutang A ke C adalah transaksi yang harus dilunasi akibat bisnis/ perdagangan di antara mereka. Hutang B ke A adalah deposit nasabah di bank atas permintaan A, B dapat melakukan pemindah bukuan untuk keuntungan $\mathrm{C}$ untuk usaha ini bank dapat mengenakan fee kepada nasabah ${ }^{15}$

Skema Hiwalah

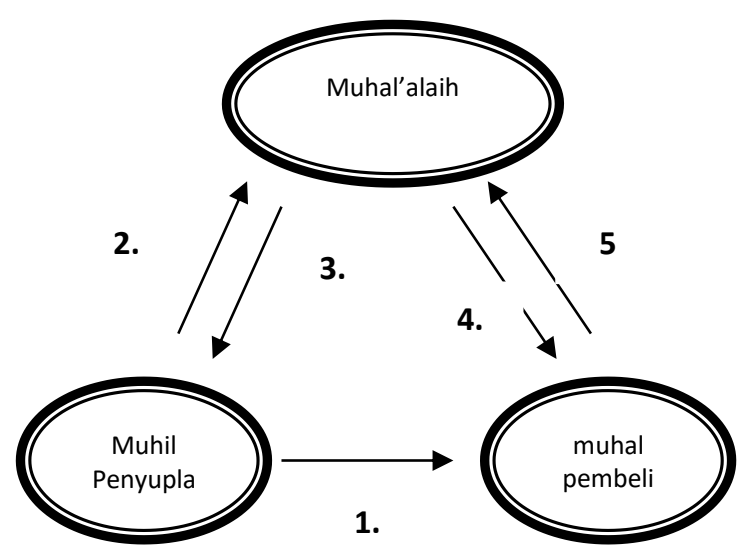

${ }^{14}$ Duddy Yustiadi, Produk Bank Syariah, (t.tpt: Tazkia Institut, t.thn), h. 25

${ }^{15}$ Lihat,- Karnaen Perwataatmadja \& Muhammad Syafe'I Antonio, op cit, h 39 


\section{Keterangan:}

\section{Suplay Barang}

2. Invoice

3. Bayar

4. Tagih

\section{Bayar}

Beberapa ketentuan dalam Hiwalah sebagai berikut:

1. Apa bila hiwalah berjalan sah, dengan senderinya tanggung jawab muhil adalah gugur. Andaikata muhal'alaih mengalami kebangkrutan atau membantah hiwalah atau meninggal dunia. Maka muhal tidak boleh kembali lagi kepada muhil, hal ini adalah pendapat ulama jumhur.

2. Menurut Imam Abu Hanifah kreditur bisa menagih piutangnya kepada debitur terdahulu, apabila debitur yang menerima pemindahan hutang itu meninggal dalam keadaan pailit atau mengingkari pemindahan hutang tersebut.

Transaksi perpindahan (take over) pembiayaan dari bank konvensional ke bank syariah diatur dalam fatwa No. 31/DSN-MUI/VI/2002 tentang pengalihan hutang. Dalam fatwa ini disebutkan ada empat alternatif akad yang dapat digunakan yaitu: ${ }^{16}$

1. Qard dan murabahah

2. Syirkah al-milk dan murabahah

3. Qard dan Ijarah

4. Qard dan Ijarah Muntahiya bit-Tamlik

Qard adalah pemberian kepada orang lain yang dapat ditagi atau diminta kembali atau dengan kata lain memimjamkan tanpa mengharap imbalan. Dalam literatur fiqhi klasik, qard dikategorikan dalam akad tathawwui atau akad saling membantu dan bukan transaksi komersil. ${ }^{17}$ Murabahah merupakan istilah yang berasal dari bahasa

${ }^{16}$ DSN-MUI, Himpunan fatwa Dewan Syariah Nasional, Cet. 3 , ed. Revisi (Ciputat: Gaung Persada), h. 185

${ }^{17}$ Muhammad Syafi'i Antonio, Bank Syariah dan Teori ke Praktek..., h. 131 
arab dari akar kata ribhu yang diartikan untung ${ }^{18}$, dimana secara sederhana murabahah diartikan sebagai sebuah bentuk transaksi jual beli yang menyebutkan modal pedagang dan keuntungan yang diperoleh dalam transaksi jual beli tersebut. Sebagian ulama mengartikan murabahah adalah jual beli barang dengan tambahan yang telah disepakati ${ }^{19}$. Syirkah: Keikutsertaan dua orang atau lebih dalam suatu usaha tertentu dengan sejumlah modal yang telah ditetap-kan berdasarkan perjanjian untuk bersamasama menjalankan suatu usaha dan pem-bagian keuntungan serta kerugian dalam bagian yang ditentukan. ${ }^{20}$ ijarah menurut bahasa berarti "upah" atau "ganti" atau “imbalan”. Karena lafaz ijarah mempunyai pengertia umum yang meliputi upah atas pemamfaatan sesuatu benda atau imbalan sesuatu kegiatan, atau upah karena melakukan sesuatu aktivitas. ijarah bermakna suatu akad yang berisi penukaran manfaat sesuatu dengan jalan memberikan imbalan dalam jumlah tertentu. Hal ini menjual manfaat dalam satu benda, bukan menjual 'ain dari benda itu. ${ }^{21}$

Dewan Syariah Nasional (DSN) menetapkan fatwa tentang pengalihan utang. Ketentuan umum dalam fatwa ini, yang dimaksud dengan pengalihan utang adalah pemindahan utang nasabah dari bank/ lembaga keuangan konvensional ke bank/ lembaga keuangan syariah. Akad dapat dilakukan melalui empat alternatif berikut:

\section{Alternatif I}

1. LKS memberikan qardh kepada nasa-bah. Dengan qardh tersebut nasabah melunasi kredit (utang)-nya; dan dengan demikian, asset yang dibeli dengan kredit tersebut menjadi milik nasabah secara penuh.

2. Nasabah menjual aset dimaksud angka 1 kepada LKS, dan dengan hasil penjualan itu nasabah melunasi qardh-nya kepada LKS.

\footnotetext{
${ }^{18}$ Asad M, Al-Kalali, Kamus Indonesia Arab (Jakarta: Bulan Bintang, 1987), h. 587

${ }^{19}$ Muhammad Taqi Usmani, An Introduction to Islamic Finance (Pakistan: Idratul Ma'arif, 2000), h. 103

${ }^{20}$ Sidiqi, Nejatullah. Kemitraan Usaha dan Bagi Hasil dalam Hukum Islam. (Jakarta: Dana Bhakti Prima Yasa 1996). Halaman 8.

${ }^{21}$ Helmi Karim, Fiqhi Muamalah-Ed.I, Cetakan.2, (Jakarta; PT. Raja Grafindo Persada, 1997), h. 29
} 
3. LKS menjual secara murabahah aset yang telah menjadi miliknya tersebut kepada nasabah, dengan pembayaran secara cicilan.

4. Fatwa DSN nomor: 19/DSN-MUI/IV-/2001 tentang al-Qardh dan Fatwa DSN nomor: 04/DSN-MUI/IV/2000 tentang Murabahah berlaku pula dalam pelaksanaan pembiayaan pengalihan utang sebagaimana dimaksud alternatif $i$ ini.

\section{Alternatif II}

1. LKS membeli sebagian aset nasabah, dengan seizin LKK; sehingga dengan demikian, terjadilah syirkah al-milk antara LKS dan nasabah terhadap asset tersebut.

2. Bagian asset yang dibeli oleh LKS sebagaimana dimaksud angka 1 adalah bagian asset yang senilai dengan utang (sisa cicilan) nasabah kepada LKK.

3. LKS menjual secara murabahah bagian asset yang menjadi miliknya tersebut kepada nasabah, dengan pembayaran secara cicilan.

4. Fatwa DSN nomor: 04/DSN-MUI/-IV/2000 tentang Murabahah berlaku pula dalam pelaksanaan Pembiayaan Pengalihan Utang sebagaimana dimak-sud dalam alternatif II ini.

\section{Alternatif III}

1. Dalam pengurusan untuk memperoleh kepemilikan penuh atas aset, nasabah dapat melakukan akad ijarah dengan LKS, sesuai dengan Fatwa DSN-MUI nomor 09/DSN-MUI/IV/2002.

2. Apabila diperlukan, LKS dapat mem-bantu menalangi kewajiban nasabah dengan menggunakan prinsip al-Qardh sesuai Fatwa DSN-MUI nomor 19/DSN-MUI/IV/2001.

3. Akad ijarah sebagaimana dimaksudkan angka 1 tidak boleh dipersyaratkan dengan (harus terpisah dari) pemberian talangan sebagaimana dimaksudkan angka 2 . 
4. Besar imbalan jasa ijarah sebagaimana dimaksudkan angka 1 tidak boleh didasarkan pada jumlah talangan yang diberikan LKS kepada nasabah sebagaimana dimaksudkan angka 2.

\section{Alternatif IV}

1. LKS memberikan qardh kepada nasabah. Dengan qardh tersebut nasabah melunasi kredit (utang)-nya; dan dengan demikian, asset yang dibeli dengan kredit tersebut menjadi milik nasabah secara penuh

2. Nasabah menjual aset dimaksud angka 1 kepada LKS, dan dengan hasil penjualan itu nasabah melunasi qardh-nya kepada LKS.

3. LKS menyewakan asset yang telah menjadi miliknya tersebut kepada nasabah, dengan akad al-Ijarah al Munta-hiyah bi al-Tamlik.

4. Fatwa DSN nomor: 19/DSN-MUI/-IV/2001 tentang al-Qardh dan Fatwa DSN nomor: 27/DSN-MUI/III/2002 tentang Ijarah al-Muntahiyah bi alTamlik berlaku pula dalam pelaksanaan Pembiayaan Pengalihan Utang sebagai-mana dimaksud dalam alternatif IV ini.

\section{PENUTUP}

Al-hawalah adalah pengalihan utang dari orang yang berhutang kepada orang lain yang wajib menanggungnya. Dewan Syariah Nasional (DSN) menetapkan fatwa tentang pengalihan utang. Ketentuan umum dalam fatwa ini, yang dimaksud dengan pengalihan utang adalah pemindahan utang nasabah dari bank/lembaga keuangan konvensional ke bank/lembaga keuangan syariah. Transaksi perpindahan (take over) pembiayaan dari bank konvensional ke bank syariah diatur dalam fatwa No. 31/DSNMUI/VI/2002 tentang pengalihan hutang. Dalam fatwa ini disebutkan ada empat alternatif akad yang dapat digunakan yaitu: ${ }^{22}$

1. Qard dan murabahah

2. Syirkah al-milk dan murabahah

22 DSN-MUI, Himpunan fatwa Dewan Syariah Nasional, Cet. 3 , ed. Revisi (Ciputat: Gaung Persada), h. 185 


\section{Qard dan Ijarah}

\section{Qard dan Ijarah Muntahiya bit-Tamlik}

Menurut Syafi'iyah bahwa rukun hiwalah itu ada empat yaitu: Pertama; Muhil (Menghilawahkan), Kedua; Muhtal (di hilawahkan), ketiga; Muhal 'alaih (orang yang menerima hiwalah, Ke empat; Shighat hiwalah, yaitu ijab dari muhil. Kontrak hawalah dalam perbankan biasanya di tetapkan pada hal-hal berikut: a. Factoring atau anjak piutang,. b. Post-dated check, c. Bill discounting. Pada proses hiwalah atau take over, bank syariah sebagai pihak yang akan melakukan take over terhadap kredit yang dimiliki calon nasabahnya di bank konvensional. Bertindak sebagai wakil dari calon nasabahnya untuk melunasi sisa kredit yang terdapat di bank asal, mengambil bukti lunas, surat asli agunan, perizinan, polis asuransi, sehingga barang (yang dikreditkan) menjadi milik nasabah secara utuh. Kemudian, untuk melunasi hutang nasabah kepada bank syariah, maka nasabah tersebut menjual kembali (barang yang dikreditkan) tersebut kepada bank syariah. Kemudian, bank syariah akan menjual lagi kepada nasabah dengan pilihan kombinasi akad yang tertera dalam Fatwa Dewan Syari'ah Nasional No: 31/DSN-MUI/VI/2002 tentang Pengalihan Hutang.

\section{DAFTAR PUSTAKA}

Al-Qur'an dan Terjemahan

Asad M, Al-Kalali, Kamus Indonesia Arab. Jakarta: Bulan Bintang, 1987

Suhendi, Hendi, Fiqhi Muamalah. Jakarta; PT. Raja Grafindo Persada, 2002

Antonio, Muhammad Syafi'I, Bank Syariah Dari Teori Ke Praktek. Jakarta; Gema Insani Press, 2001

Tazkia Institut, 1999

Dewan Syariah Nasional - Majelis Ulama Indonesia, Fatwa Dewan Syariah Nasional No. 31 / DSN - MUI / VI/ 2002 Tentang Pengalihan Hutang 
Husein al-Munawar, Said Agil, Hukum Islam dan Pluralitas sosial, Jakarta: Penamadani, 2004

Karim, Helmi, Fiqhi Muamalah-Ed.I, Cet.2, Jakarta; PT. Raja Grafindo Persada, 1997

Sjahdeini, Sutan Remy, Perbankan Islam dan Kedudukannya dalam tata Hukum Perbankan Indonesia, cet. 1. Jakarta: Pustaka Utama Grafiti, 1999

Sidiqi, Nejatullah. Kemitraan Usaha dan Bagi Hasil dalam Hukum Islam. Jakarta: Dana Bhakti Prima Yasa, 1996.

Suhendi, Hendi, Fiqhi Muamalah. Jakarta; PT. Raja Grafindo Persada, 2002

Usmani, Muhammad Taqi, An Introduction to Islamic Finance, Pakistan: Idratul Ma'arif, 2000

Perwataatmadja, Karnaen \& Antonio, Muhammad Syafe'I, Apa dan Bagaimana Bank Islam. Yogyakarta; Dana Bhakti Wakaf, 1992

Ya'qub, Hamzah, Kode Etik Dagang Menurut Islam, "Pola Pembinaan Hidup Dalam Berekonomi” Cet. III. Bandung, CV. Diponegoro Bandung, 1999

Yustiadi, Duddy, Produk Bank Syariah, t.tpt: Tazkia Institut. 